\title{
The C-terminal domain (CTD) in linker histones antagonizes anti-apoptotic proteins to modulate apoptotic outcomes at the mitochondrion
}

\author{
M Garg ${ }^{1,2}$, R Ramdas $^{1}$, M Vijayalakshmi ${ }^{1,4}$, GV Shivashankar ${ }^{1,3}$ and A Sarin ${ }^{\star, 1}$
}

The loss of mitochondrial integrity as a consequence of apoptogenic complexes formed on the outer membrane constitutes a key step in controlling progression of apoptotic cascades. Here, we show that multiple members of the linker histone (LH) family of proteins modify apoptotic cascades initiated by the Bcl-2 protein Bak, and impart resistance to its endogenous antagonist $\mathrm{Bcl}-\mathrm{xL}$. Our experiments reveal apoptogenic capabilities equivalent to those documented for $\mathrm{H} 1.2$ in $\mathrm{H} 1.1$ and $\mathrm{H} 1.3$ isoforms. Deletion mutants of H1.2 and site-directed mutagenesis of H1.1 and H1.2 implicated the C-terminal domain in apoptogenic activity. In this context, disruption of protein kinase-C activity using chemical inhibitors, dominant-negative approaches and RNA interference coupled with site-directed modifications in $\mathrm{H} 1.1$, identified the protein kinase-C $\beta 1$ isoform as a repressor of H1.1/H1.3 apoptogenic activity. Finally, a H1.2 C-terminal tail recombinant attenuated Bcl-xl inhibition of Bak-induced apoptosis, suggesting that the $\mathrm{C}$-terminal domain was necessary and sufficient for apoptogenic functions. Thus, integration with apoptotic intermediates (via C-terminal tail interactions) may constitute a more generalized function of LH isoforms in apoptotic cascades. Cell Death and Disease (2014) 5, e1058; doi:10.1038/cddis.2014.20; published online 13 February 2014

Subject Category: Cancer

$\mathrm{Bcl}-2$ family proteins determine mitochondrial involvement in death cascades that eliminate damaged and defective cells . ${ }^{1,2}$ In mammalian cells, apoptosis may be coordinated by transmembrane proteins of the Tumor Necrosis Receptor superfamily, ${ }^{3}$ which respond to extracellular signals to activate preformed adapter proteins and cytotoxic intermediates. Apoptosis is also initiated by internal stressors that in response to varied cues recruit adapter proteins, predominantly of the $\mathrm{Bcl}-2$ family, to precipitate the release of apoptogenic intermediates from the mitochondrion., ${ }^{1,2}$ Damage to the genome triggers the latter pathway, 4,5 suggesting possible mechanisms that relay apoptotic signals to the mitochondrion. Apart from the well-studied protein p53, which has been extensively investigated in this context, ${ }^{6,7}$ molecular intermediates such as Nur77, caspase-2 and more recently the linker histone (LH) H1.2 have been demonstrated to transmit apoptogenic signals from the nucleus to the mitochondrion in response to genotoxic damage..$^{8,9}$

The LHs, which comprise eight subtypes, consist of a highly conserved globular domain and less conserved $\mathrm{N}$-and C-terminal domains. The C-terminal domain (CTD) of the $\mathrm{LH}$ generally includes $\sim 40 \%$ lysine residues, $20-35 \%$ alanine residues and $15 \%$ proline residues. ${ }^{10}$ Two distinct functional regions of 24 amino acids each that facilitate DNA binding and chromatin condensation have also been described. ${ }^{11}$ Specific regions in the CTD have been shown to facilitate proteinprotein interactions with binding affinities of LHs thought to be determined by the length of the C-terminal tail. ${ }^{10,12,13}$ Consistent with this, measures of LH dynamics by fluorescence recovery after photobleaching (FRAP) analysis have shown that isotypes $\mathrm{H} 1.3, \mathrm{H} 1.4$ and $\mathrm{H} 1.5$ with longer CTDs exchange slowly ( $\left.t_{1 / 2} \sim 15 \mathrm{~min}\right)$, when compared with $\mathrm{LH}$ with shorter CTDs (H1.0, H1.1 and $\mathrm{H} 1.2)$ and faster $t_{1 / 2}$ of $1-2$ min. ${ }^{12}$ Indeed, the dynamics of LH is a key feature thought to underlie varied outcomes characterized by LH involvement. ${ }^{14-17}$ In this context, the molecular logic underlying the singular involvement of $\mathrm{LH}$ isoform $\mathrm{H} 1.2$ in apoptotic cascades or interactions at the mitochondrial outer membrane is not known.

In this study, using recombinant approaches we characterize components of multi-protein apoptogenic complexes that characterize $\mathrm{LH}$ functions at the mitochondrion. We also investigate intrinsic properties of LHs controlling apoptogenic function using functional and biophysical assays. Validating predictions from these experiments, we demonstrate that proapoptotic functions of $\mathrm{LH}$ isoforms $(\mathrm{H} 1.1, \mathrm{H} 1.2$ and possibly $\mathrm{H} 1.3$ ) reside in the CTD and are demonstrable in the context of apoptosis triggered by the proapoptotic Bak and its regulation by $\mathrm{Bcl}-\mathrm{xL}$.

\footnotetext{
${ }^{1}$ National Centre for Biological Sciences, Bangalore, India; ${ }^{2}$ Department of Biotechnology, Mysore University, Mysore, India and ${ }^{3}$ Mechanobiology Institute, National University of Singapore, Singapore

*Corresponding author: A Sarin, National Centre for Biological Sciences, Bellary Road, Bangalore 560065, Karnataka, India. Tel: +91 8023666080 ; Fax: +91802366 6462; E-mail: sarina@ncbs.res.in

${ }^{4}$ Current address: SASTRA University, Thanjavur, Tamil Nadu, India

Keywords: apoptosis; Bak; H1.2-CTD; linker histone; PKC

Abbreviations: AIF, apoptosis inducing factor; BAK, Bcl-2 homologous antagonist killer; Bcl-2, B-cell lymphoma 2; Bcl-xL, B-cell lymphoma-extra large; BIM1, Bisindoylmaleimide I; CTD, C-terminal domain; DNC9, dominant-negative caspase 9; Drp1, dynamin-related protein 1; FRAP, fluorescence recovery after photobleach; HKII, hexokinase-II; LH, linker histone; LMB, leptomycin B; Mfn, mitofusin; MIMS, mitochondrial inter-membrane space; PKC, protein kinase-C; PUMA, p53 upregulated modulator of apoptosis

Received 11.10.13; revised 03.1.14; accepted 07.1.14; Edited by A Stephanou
} 


\section{Results}

H1.2 modulates anti-apoptotic activity. The Bcl-2 family protein $\mathrm{Bcl}-\mathrm{xL}$ is a well-characterized antagonist of Bakinduced apoptosis; however, its anti-apoptotic activity was attenuated in cells coexpressing recombinant linker histone $\mathrm{H} 1.2$ and Bak (Figure 1a). Notably, recombinant H1.2 did not trigger apoptosis when expressed alone, nor did it increase Bak-induced apoptotic damage (Figure 1a). Analyses by confocal microscopy indicated that $\mathrm{H} 1.2$ (tagged with EGFP) did not modify the spatial patterns of Bak (RFP-tagged) distribution in cells (Figure 1b). However, Bcl-xL successfully inhibited apoptosis when Bak was coexpressed with the $\mathrm{H} 1.1$ isoform (Figure 1c). Although Bax and Bak have several overlapping structural and functional features, H1.2 did not modulate $\mathrm{Bcl}-\mathrm{xL}$ regulation of Bax activity (Figure $1 \mathrm{~d}$ ). Consistently, Bak-H1.2 induced apoptosis, in the presence or absence of $\mathrm{Bcl}-\mathrm{xL}$, in cells treated with siRNA to Bax (Supplementary Figures $1 \mathrm{~A}$ and $\mathrm{B}$ ). The apoptogenic capabilities of $\mathrm{H} 1.2$ were not restricted to $\mathrm{Bcl}-\mathrm{xL}$ as hexokinase-Il-mediated inhibition of Bak activity was also attenuated in cells coexpressing H1.2 (Figure 1e). Inhibition of nuclear export machinery, using leptomycin B (LMB) blocked the effect of $\mathrm{H} 1.2$, implicating signaling from the nucleus in this cascade (Figure 1f). To understand the mechanism underlying $\mathrm{H} 1.2$ activity, molecular intermediates of the apoptotic pathway triggered in cells expressing Bak and $\mathrm{H} 1.2$ were characterized in the experiments that follow.
H1.2 reprograms Bak-mediated apoptotic outputs. In most instances, Bak is thought to compromise mitochondrial outer membrane integrity to release cytochrome $c$ from the inter-membrane space (MIMS), which catalyzes the activation of a caspase-9-dependent apoptotic cascade. ${ }^{18}$ However, Bak and H1.2 (Bak-H1.2)-activated apoptosis was not inhibited by coexpressing a dominant-negative form of caspase-9 (Figure 2a), suggesting that cytochrome $c$ was not a key intermediate in Bak-H1.2-induced death. Apoptosisinducing factor (AIF) is another resident of the MIMS that is released following the loss of mitochondrial outer membrane integrity and translocates to the nucleus and causes DNA fragmentation. ${ }^{19}$ Knockdown of AIF using RNA interference blocked Bak-H1.2-mediated apoptosis, positioning the molecule as a key intermediate in this signaling pathway (Figure 2b). Notably, AIF ablation was without effect on apoptosis induced by Bak or Bak-H1.1 (Figure 2b), although apoptotic damage is not different in the three groups. In this context, AIF translocation to the nucleus was detected in cell populations transfected with Bak-H1.2, whereas in cells transfected with Bak-H1.1, AIF was detected in the nonnuclear fraction (Figure 2c), which is consistent with its regulation of Bak-H1.2-dependent apoptosis. Phosphorylation of histone H2AX-Ser139 $(\gamma-\mathrm{H} 2 \mathrm{AX})$ is a hallmark of DNA damage $^{20}$ and a molecular signature of AIF activity. ${ }^{21}$ Supporting the involvement of AIF in Bak-H1.2-induced apoptosis, $\gamma \mathrm{H} 2 \mathrm{~A} . \mathrm{X}$ reactivity was detected in cell lysates generated from Bak-H1.2 transfected cells and not in the Bak transfected group, although H2A.X was comparable in both

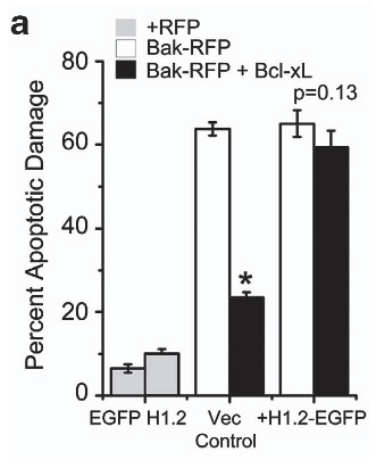

b
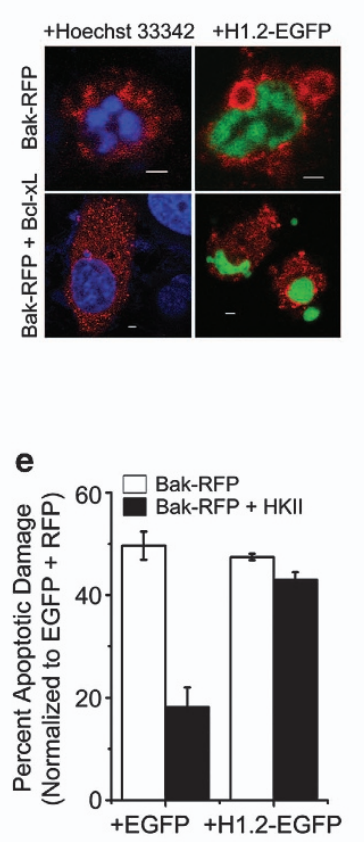

c
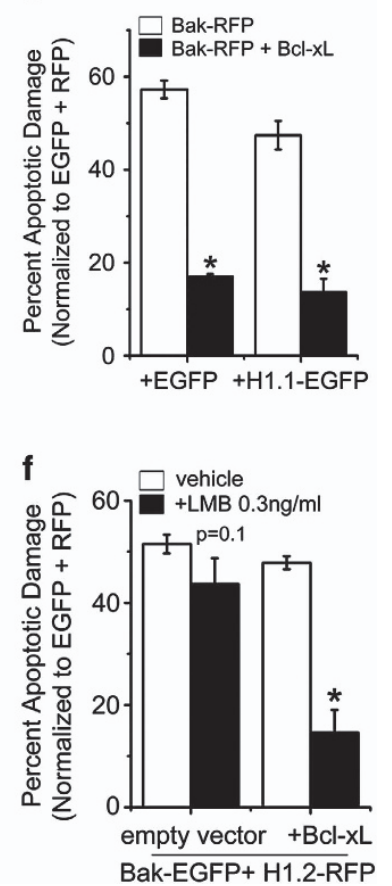

Figure 1 H1.2 modulates Bak-mediated apoptosis (a) Apoptotic nuclear damage in cells co-transfected with EGFP or Bak-RFP or Bak-RFP + H1.2-EGFP with or without $\mathrm{Bcl}-\mathrm{xL}$ and (b) Confocal images of transfected cells (representative of minimum 60 cells). Scale bar, $5 \mu \mathrm{m} ;{ }^{*} P<0.001$ (c and d) Apoptotic nuclear damage induced by Bak-RFP \pm H1.1-EGFP (c) or with Bax-EGFP \pm H1.2-RFP (d) transfected with or without Bcl-xL. (e and f) Apoptotic nuclear damage in cells transfected with (e) Bak-RFP or Bak-RFP + H1.2-EGFP with or without HKII (hexokinase-II); or (f) Bak-EGFP $+\mathrm{H} 1.2-\mathrm{RFP} \pm \mathrm{Bcl}-\mathrm{xL}$ treated with LMB $(0.3 \mathrm{ng} / \mathrm{ml})$ or vehicle control added $6 \mathrm{~h}$ post-transfection. In a, $\mathbf{c}$ and $\mathbf{d}-\mathbf{f}$, apoptotic damage was assessed $18 \mathrm{~h}$ post-transfection. Data plotted are mean \pm S.D. from three independent experiments 
a

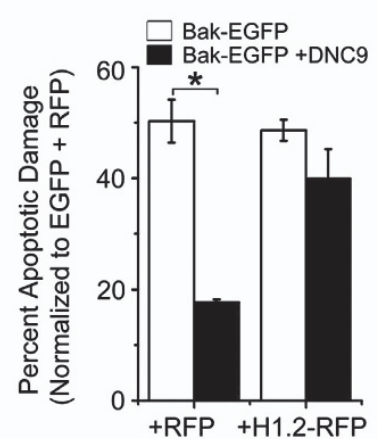

b

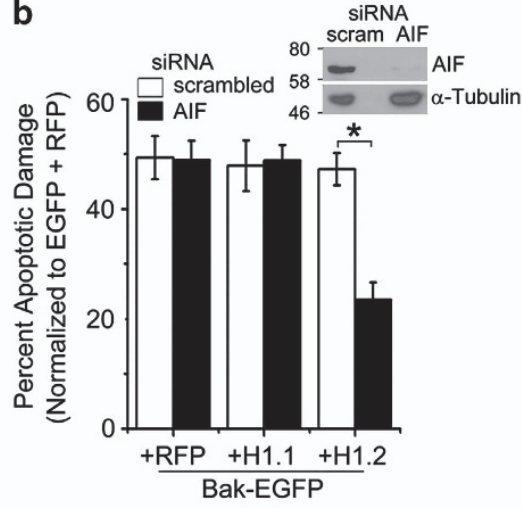

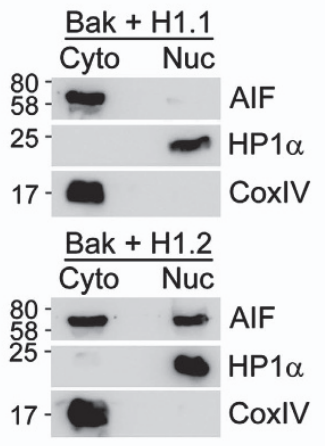

d

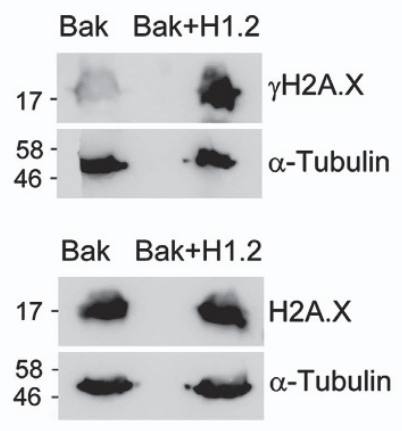

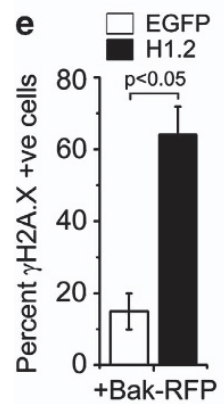
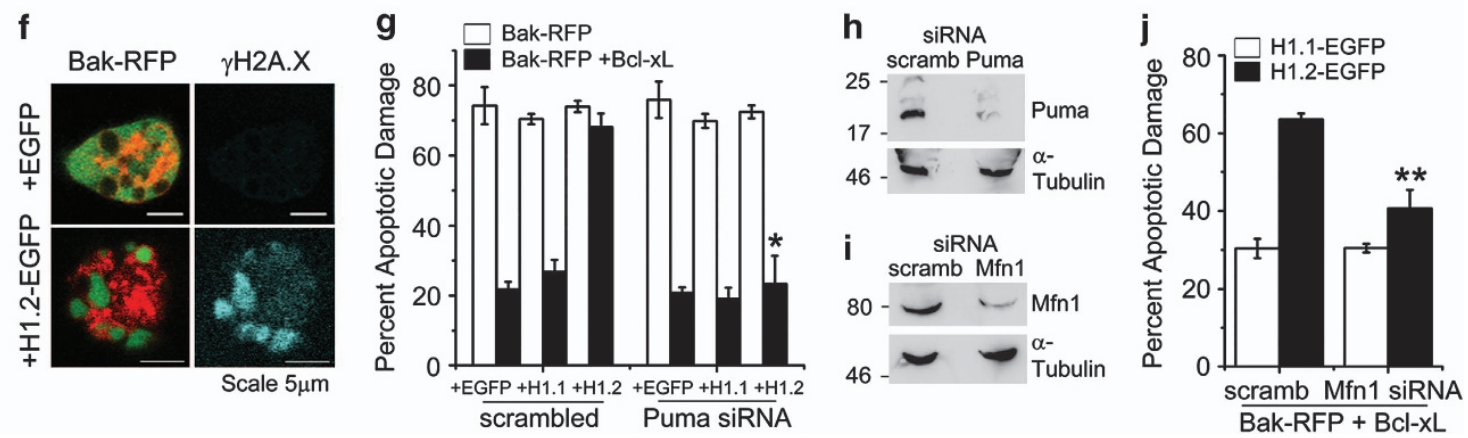

Figure 2 AlF regulates Bak-H1.2-mediated apoptosis (a and $\mathbf{b})$ Apoptotic nuclear damage in cells (a) transfected with Bak-EGFP or Bak-EGFP + H1.2-RFP with or without DNC9 (b) pretreated with siRNA to AIF or the scrambled control for $48 \mathrm{~h}$ and then transfected with Bak-EGFP or Bak-EGFP + H1.1-RFP or Bak-EGFP + H1.2-RFP. Inset: Representative immunoblot for AIF protein and $\alpha$-tubulin in cells treated with siRNA to AIF. (c) Immunoblots derived from subcellular fractionation of experimental groups transfected with indicated plasmids and cultured for $12 \mathrm{~h}$. The fractions were probed for AIF, HP1 $\alpha$ and Cox-IV. (d) Cells transfected with Bak-RFP or Bak-RFP + H1.2-EGFP were cultured for $12 \mathrm{~h}$ and cell lysates analyzed for $\gamma \mathrm{H} 2 \mathrm{~A} . \mathrm{X}$ and unmodified H2A.X protein by western blot analysis. Tubulin established parity of loading. (e and f) Quantification of $\gamma$ H2A.X-positive cells (e) in groups transfected with Bak-RFP + GFP or Bak-RFP + H1.2-EGFP. Representative confocal images of immunostaining for $\gamma H 2 A . X(f)$, from the analysis of $\sim 75$ cells for each condition from two experiments is shown. ( $\mathbf{g}-\mathbf{j})$ Apoptotic damage in cells pretreated for $48 \mathrm{~h}$ with siRNA to PUMA or the scrambled control (g) or Mfn1 (j) and transfected with indicated combination of recombinants. Immunoblots for PUMA (h) and Mfn1 (i) protein in cells treated with respective siRNA. $\alpha$-tubulin was used as the loading control. In $\mathbf{a}, \mathbf{b}, \mathbf{g}$ and $\mathbf{j}$, apoptotic nuclear damage was scored $18 \mathrm{~h}$ post-transfection. Data plotted are mean \pm S.D. from three independent experiments. ${ }^{*} P<0.001{ }^{* *} P<0.01$

groups (Figure 2d). Immunostaining for $\gamma \mathrm{H} 2 \mathrm{~A} . \mathrm{X}$ yielded positive staining in cells transfected with Bak-H1.2, whereas the modified form was not detected in cells co-transfected with Bak and GFP (Figures $2 e$ and $f$ and Supplementary Figures $2 \mathrm{~A}$ and $\mathrm{B}$ ). Again the extent of apoptotic nuclear damage is not different in these groups. Collectively, these experiments demonstrate that $\mathrm{H} 1.2$ has distinct consequences for Bak regulation and activity, albeit apoptotic signaling is coordinated by mitochondrial intermediates.

Molecular complexes formed on the mitochondrial outer membrane regulate the release of intermediates sequestered in the organelle, which propagate apoptotic cascades. Bak is a mitochondrial resident and its activity is controlled by ligands such as $\mathrm{BH} 3$ domain-only proteins ${ }^{22,23}$ and molecules controlling mitochondrial remodeling. ${ }^{24,25}$ Therefore, we assessed whether complexes formed by Bak and Bak-H1.2 differed in molecular constitution. Ablation (using siRNA) of the $\mathrm{BH} 3$ domain only proteins BIM or BID was without effect on Bak-H1.2 signaling (Supplementary Figures 2C-F). However, the adapter protein PUMA (p53-upregulated modulator of apoptosis) was critical for apoptotic signaling, as its ablation attenuated $\mathrm{H} 1.2$ activity and restored $\mathrm{Bcl}-\mathrm{xL}$ function (Figures $2 \mathrm{~g}$ and h). Similar approaches demonstrated a requirement for a protein regulating mitochondrial fusion, mitofusin-1 (Mfn-1) but not the Mfn-2 isoform or the dynaminrelated protein (Drp)-1, which controls organelle fission, in the Bak-H1.2 apoptotic cascade (Figures $2 \mathrm{i}$ and $\mathrm{j}$ and Supplementary Figures $2 \mathrm{G}-\mathrm{J}$ ). These experiments indicate a distinct configuration of molecules forming apoptogenic complexes associated with Bak-H1.2 activity, perhaps determining the release of intermediates from the mitochondria. Subsequent experiments attempted to identify specific domains in $\mathrm{H} 1.2$ that control its activity in the mitochondrion.

Molecular characterization of linker histone activity in the apoptotic response. LH isoforms are distinguished by the sequences of their $\mathrm{N}$ - and $\mathrm{C}$-terminal tails ${ }^{12,14}$ and we focused on the tail domains to examine intrinsic determinants of apoptogenic activity. As shown for $\mathrm{H} 1.1$, coexpressing $\mathrm{H} 1.3$ or $\mathrm{H1} .5$ with Bak did not confer resistance to $\mathrm{Bcl}-\mathrm{xL}$ (Figures $3 a$ and $b$ ). More careful examination of the C-terminal tails revealed that the motif KVVKP, which appears only once in $\mathrm{H} 1.2$, differed from the motif (present multiple times) in $\mathrm{H} 1.1$ and $\mathrm{H} 1.3$ by a threonine residue (KTAKP) (Figure $3 \mathrm{c}$ and Supplementary Figure 3A). To test whether this was critical for the functional differences observed, site-directed substitution of Valine-202 to Threonine was employed to generate the $\mathrm{H} 1.2$ variant $\mathrm{H} 1.2 \mathrm{~V} 202 \mathrm{~T}-\mathrm{EGFP}$. 

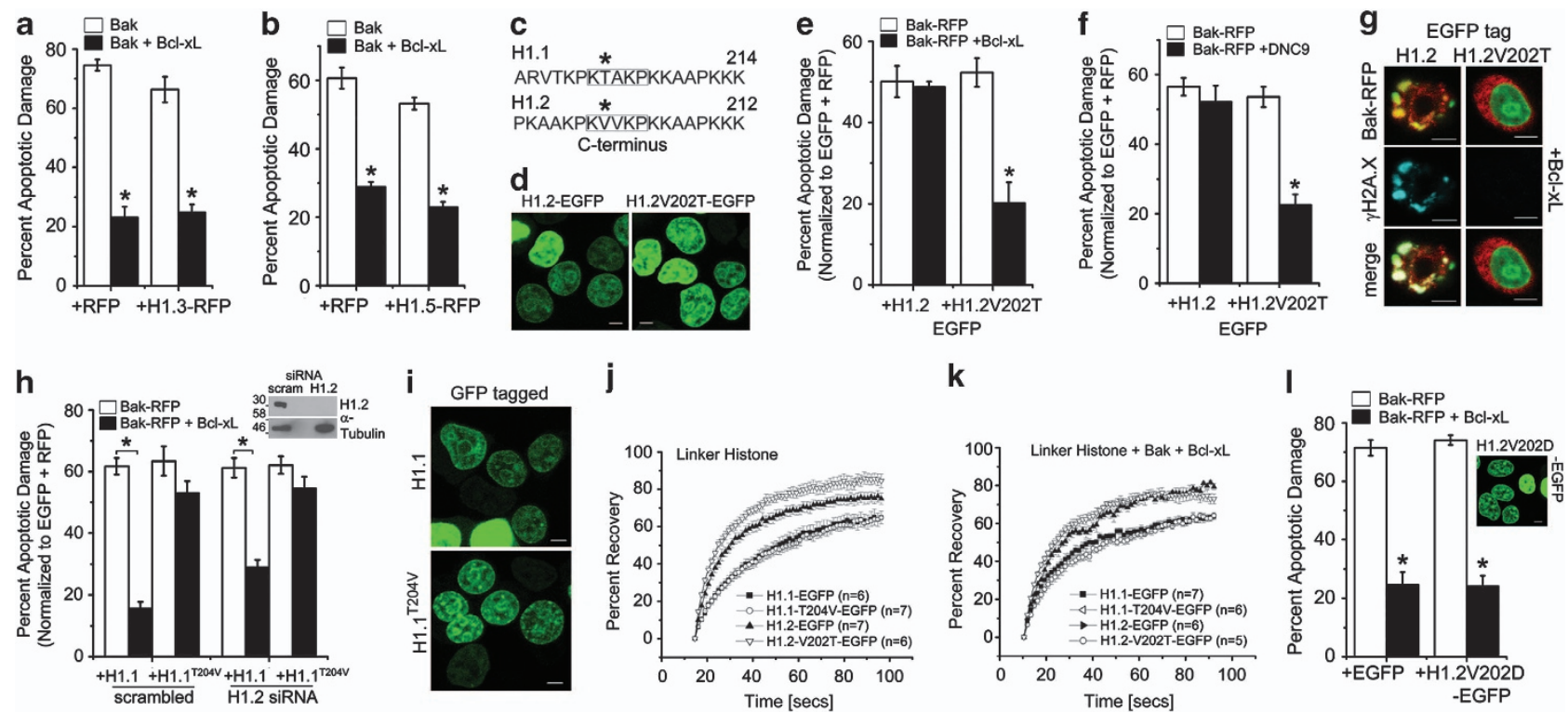

Figure 3 Characterization of H1.2 domains modulating Bak-mediated apoptosis (a and $\mathbf{b}$ ) Apoptotic nuclear damage in cells transfected with Bak-EGFP and BakEGFP + H1.3-RFP (a) or Bak-EGFP + H1.5-RFP (b) with or without Bcl-xL. ${ }^{*} P<0.001$ (c) Schematic representation of a part of amino acid sequence of the CTD of H1.1 and H1.2. The asterisk $\left(^{*}\right)$ indicates the amino acid residue mutated within the boxed motif. The numbers indicate total amino acid residues in each isoform. (d) Representative confocal images showing nuclear localization of EGFP-tagged H1.2 or H1.2V202T recombinant in HeLa cells (representative of minimum 100 cells). Scale bar, $5 \mu \mathrm{m}$ (e and f) Apoptotic damage in cells expressing Bak-RFP co-transfected with H1.2 recombinants with or without Bcl-xL (e) or DNC9 (f). (g) Confocal images of cells expressing the different H1.2 recombinants with Bak-RFP + Bcl-xL and $12 \mathrm{~h}$ post-transfection, immunostained with an antibody to $\gamma \mathrm{H} 2 \mathrm{~A}$.X (Ser 139). Scale bar, $5 \mu \mathrm{m}$ (h) Apoptotic damage in cells pretreated with siRNA to $\mathrm{H} 1.2$ or the scrambled control for $48 \mathrm{~h}$ and then transfected with Bak $+\mathrm{H} 1.1$ or Bak $+\mathrm{H} 1.1^{\mathrm{T} 204 \mathrm{~V}}$ with or without Bcl-xL. Inset: Immunoblot for $\mathrm{H} 1.2$ and $\alpha$-tubulin protein in cells treated with siRNA to H1.2. (i) Representative confocal images showing nuclear localization of EGFP-tagged H1.1 recombinants (representative of minimum 50 cells). Scale bar, $5 \mu \mathrm{m}$ (j and $\mathbf{k}$ ) FRAP analysis in the nucleus of cells expressing H1.1-EGFP or H1.2-EGFP recombinants with or without $\mathrm{Bak}+\mathrm{Bcl}-\mathrm{xL}, 12 \mathrm{~h}$ post-transfection. Percentage recovery is plotted for a period of $100 \mathrm{~s}$. Data are presented as mean \pm S.E.M. (I) Apoptosis induced by Bak-RFP or BakRFP + H1.2V202D-EGFP with or without Bcl-xL. Inset: Representative confocal image showing nuclear localization of EGFP-tagged H1.2V202D recombinant (representative of 75 cells). Scale bar, $5 \mu \mathrm{m}$ Apoptotic nuclear damage was assessed $18 \mathrm{~h}$ post-transfection. In $\mathbf{a}, \mathbf{b}, \mathbf{e}, \mathbf{h}$ and $\mathbf{i}$, data plotted are mean \pm S.D. from three independent experiments and in $\mathbf{f}$, from four independent experiments

H1.2V202T localized to the nucleus, as assessed by confocal microscopy (Figure 3d). Apoptosis induced by coexpressing Bak and the H1.2V202T recombinant was inhibited by Bcl-xL and DNCasp-9 (Figures $3 e$ and f) and $\gamma$-H2A.X reactivity was not elicited in Bak-H1.2V202T expressing cells (Figure $3 \mathrm{~g}$ ) strongly suggesting that the KVVKP sequence controlled functions in H1.2. This prompted a reciprocal change in the $\mathrm{H} 1.1$ isoform, to generate the H1.1T204V recombinant. Apoptosis triggered by coexpressing H1.1T204V with Bak, was not attenuated by the ablation of endogenous $\mathrm{H} 1.2$ and was resistant to regulation by $\mathrm{Bcl}-\mathrm{xL}$ (Figure $3 \mathrm{~h}$ ), thereby mimicking apoptogenic functions of $\mathrm{H} 1.2$. The modified $\mathrm{H} 1.1$ recombinant was also localized to the nucleus (Figure 3i). Further, LMB restored $\mathrm{Bcl}-\mathrm{xL}$ regulation of Bak-H1.1T204V-mediated apoptosis (Supplementary Figure 3B). Despite the differences in assays of apoptosis, the dynamics of the linker histone mutants are consistent with earlier studies ${ }^{13}$ and the modified recombinants were comparable to the parent proteins (in the presence or absence of Bak-Bcl-xL), (Figures $3 \mathrm{j}$ and $\mathrm{k}$ and Supplementary Figures $3 \mathrm{C}-\mathrm{E})$ suggesting that chromatin compaction functions of the LHs were not changed. We then considered that the threonine residue in the H1.1 C-terminal tail was a site for posttranslational modification, which controlled its nonnuclear (apoptogenic) activity. This possibility was supported by the observation that upon substitution with a negatively charged amino acid, the resultant H1.2V202D recombinant (possibly functioning as a phospho-mimetic) did not attenuate $\mathrm{Bcl}-\mathrm{xL}$ activity (Figure 3l).

LH functions are regulated by protein kinase-C (PKC) activity. Further examination of the C-terminal tail sequences suggested that the motif (KTAKP) might be a putative PKC- $\alpha / \beta$ target site (Supplementary Figure $3 \mathrm{~A}$ ). We first tested the outcome of modifying PKC activity (on $\mathrm{H} 1.1$ and $\mathrm{H} 1.3$ in apoptosis assays), using pharmacological approaches. In the presence of Gö6976 or BIM-1, inhibitors of PKC enzymes, coexpression of $\mathrm{H} 1.1$ or $\mathrm{H} 1.3$ attenuated Bcl-xL activity (Figures $4 a$ and $b$ and Supplementary Figure 4A), whereas coexpression of H1.5 did not modulate Bcl-xL activity (Figure $4 \mathrm{~b}$ and Supplementary Figure $4 \mathrm{~A}$ ). We show the loss of phospho-PKC activity, assessed by immunoblot analysis of lysates prepared from cells treated with the PKC inhibitors (Figure $4 \mathrm{c}$ and Supplementary Figure 4B). As PKC can regulate core histone functions, ${ }^{26,27}$ we extended the analysis to the induced phosphorylation by PKC of core histone H3-GFP and ascertained, as reported by others, ${ }^{26}$ that this is sensitive to inhibition by BIM-1 (Supplementary Figures 4C and D). Next, we asked whether modulation of PKC activity impinged on nuclear dynamics of the LH proteins. As before, FRAP measures for this analysis revealed no differences in LH dynamics following treatment 

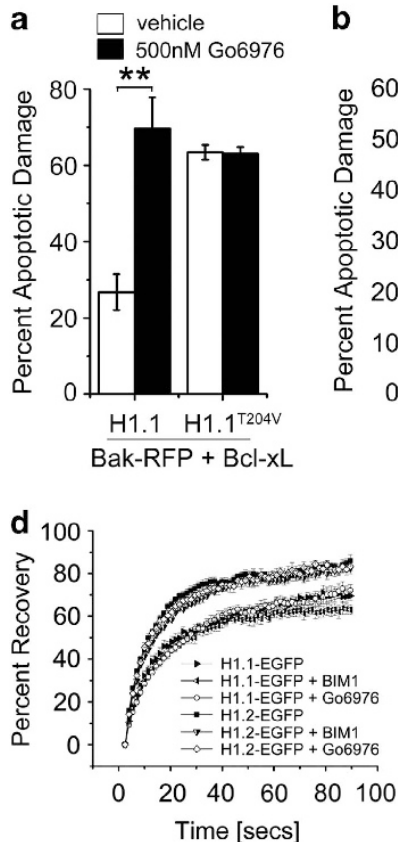
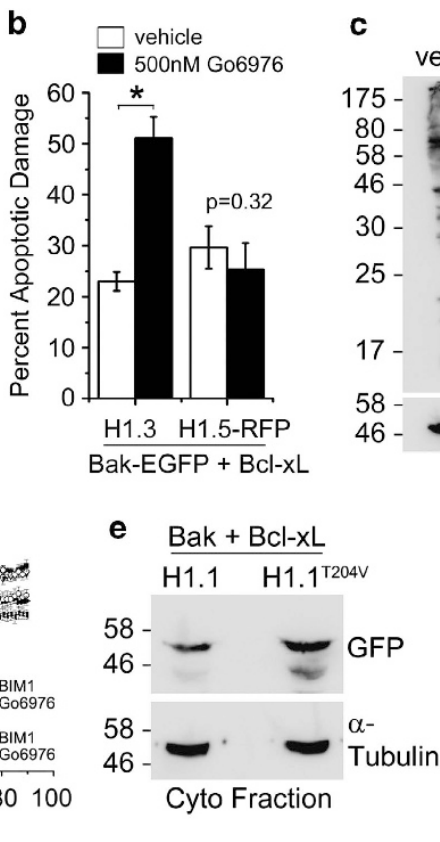
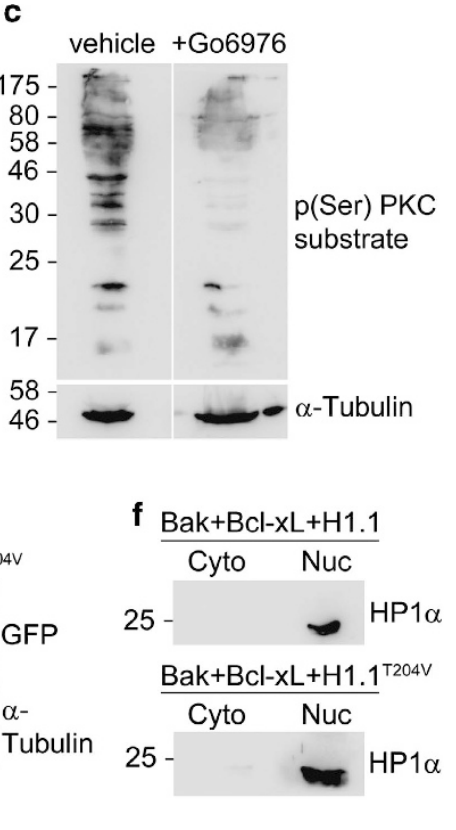

Figure 4 Regulation of LH function by PKC (a and $\mathbf{b}$ ) Apoptotic nuclear damage in cells transfected with (a) Bak $+\mathrm{H} 1.1$ or Bak $+\mathrm{H} 1.1-\mathrm{T} 204 \mathrm{~V}$ or (b) Bak $+\mathrm{H} 1.3$ or Bak $+\mathrm{H} 1.5$ with Bcl-xL, with Gö6976 ( $500 \mathrm{nM}$ ) or vehicle control added $6 \mathrm{~h}$ post-transfection for a total culture duration of $18 \mathrm{~h}$. Data plotted are mean \pm S.D. from three independent experiments. (c) Representative immunoblot for phospho(Ser)-PKC substrate protein and $\alpha$-tubulin in cells treated with Gö6976 (500 nM) or vehicle control for $12 \mathrm{~h}$. The spacer indicates one lane removed during processing of the image for presentation. (d) FRAP analysis in the nucleus of cells expressing H1.1-EGFP or H1.2-EGFP recombinants, with $500 \mathrm{nM}$ BIM1 or Gö6976 added $6 \mathrm{~h}$ post-transfection. Percentage recovery is plotted for a period of $100 \mathrm{~s}(n=15$ for $\mathrm{H} 1.1-\mathrm{EGFP}, n=12$ for $\mathrm{H} 1.1+\mathrm{BIM} 1$, $n=13$ for H1.1 + Gö6976, $n=10$ for H1.2-EGFP, $n=8$ for H1.2 + BIM1 and $n=9$ for H1.2 + Gö6976). Data plotted are mean \pm S.E.M. (e and f) Immunoblots of nuclear and cytoplasmic fractions of HEK cells transfected with indicated recombinants for $12 \mathrm{~h}$ and probed for GFP and $\alpha$-tubulin (e) and with HP1 $\alpha$ (f) purity control

with the PKC inhibitors, suggesting that PKC activity may not modulate LH mobility in the nucleus (Figure 4d and Supplementary Figures 4E and F). Further, cell fractionations followed by immunoblot analysis indicated that unmodified $\mathrm{H} 1.1$ protein was detected in the cytoplasm, as was the H1.1T204V recombinant (Figures $4 \mathrm{e}$ and $\mathrm{f}$ and Supplementary Figures $4 \mathrm{G}$ and $\mathrm{H}$ ). It may be noted, however, that these observations may arise from the enhanced mobility of LHs when compared with the lessmobile HP1 $\alpha$ protein used to mark the nuclear fraction. However, the PKC modification, while not affecting activities in the nucleus, may stabilize LH function in the cytoplasm, although the underlying mechanism(s) remains to be ascertained.

Dominant-negative and RNAi approaches were used to identify isoform(s) of the PKC family that regulated this activity. Ablation of the PKC $\alpha$ or PKC- $\beta$ isoforms using RNAi indicated a requirement for the latter in the regulation of $\mathrm{H} 1.1$ apoptogenic activity (Figures $5 \mathrm{a}$ and $\mathrm{b}$ ). The regulation was lost with $\mathrm{H} 1.1 \mathrm{~T} 204 \mathrm{~V}$ and restored when $\mathrm{H} 1.2 \mathrm{~V} 202 \mathrm{~T}$ was included in functional assays (Figures $5 \mathrm{c}$ and $\mathrm{d}$ ). Dominantnegative approaches revealed that the PKC- $\beta 1$ and not the PKC- $\beta 2$ isoform regulated this activity (Figures 5 e and f). To more directly test the involvement of the CTD suggested by the aforementioned experiments, we undertook a deletionmutation analysis of $\mathrm{H} 1.2$.

The H1.2 CTD is required for apoptogenic activity. A tailless $\mathrm{H} 1.2$ recombinant $\left(\mathrm{H} 1.2^{\mathrm{TL}}\right)$ did not regulate $\mathrm{Bcl}-\mathrm{xL}$ function vis-a-vis Bak-induced apoptosis (Figure 6a), positing the tail regions as key molecular regulators of $\mathrm{H} 1.2$ function. Further, an N-terminal-deleted form of $\mathrm{H} 1.2\left(\mathrm{H} 1.2^{\Delta \mathrm{NTD}}\right)$ retained apoptogenic activity, attenuating $\mathrm{Bcl}-\mathrm{xL}$ regulation of Bak-induced apoptosis as efficiently as the full-length $\mathrm{H} 1.2$ (Figure 6b) implicating the CTD in apoptotic function. In addition, the dynamics of $\mathrm{H} 1.2^{\Delta \mathrm{NTD}}$ as measured by FRAP analysis was only moderately different from parent $\mathrm{H} 1.2^{28}$ (Supplementary Figures 5A and B). As a consequence of all the analyses thus far, we tested whether a $\mathrm{C}$-terminal tail recombinant of $\mathrm{H} 1.2$ recapitulated apoptogenic capabilities of full-length H1.2. In initial experiments, ectopic expression of the H1.2 C-terminal tail-EGFP $\left(\mathrm{H} 1.2^{\mathrm{CTD}}\right)$, when coexpressed with $\mathrm{Bak}$ and $\mathrm{Bcl}-\mathrm{xL}$ was without effect in that there was no attenuation of $\mathrm{Bcl}-\mathrm{xL}$ function (Figure $6 \mathrm{c}$ ). Whereas this experiment indicates that H1.2 CTD does not have apoptogenic activity, western blot analysis for the GFP-tagged CTD recombinant in cells suggested that the CTD was being degraded, as it was only weakly detected in cell lysates (Figure 6d). However, in lysates generated from cells cultured in the presence of MG-132-a cell-permeable, broad-spectrum, protease inhibitor-the CTD recombinant was readily detected in immunoblots (Figure $6 \mathrm{~d}$ ). This suggested that the lack of apoptogenic activity of the CTD in functional assays might be attributed to its degradation. In support of this, in cultures treated with MG132, H1.2 ${ }^{\text {CTD }}$ attenuated $\mathrm{Bcl}-\mathrm{xL}$ activity (Figure $6 \mathrm{e}$ ). We could rule out the possibility that this was an artifact induced by MG132 as the inhibitor did not modulate outcomes in cells that were not 

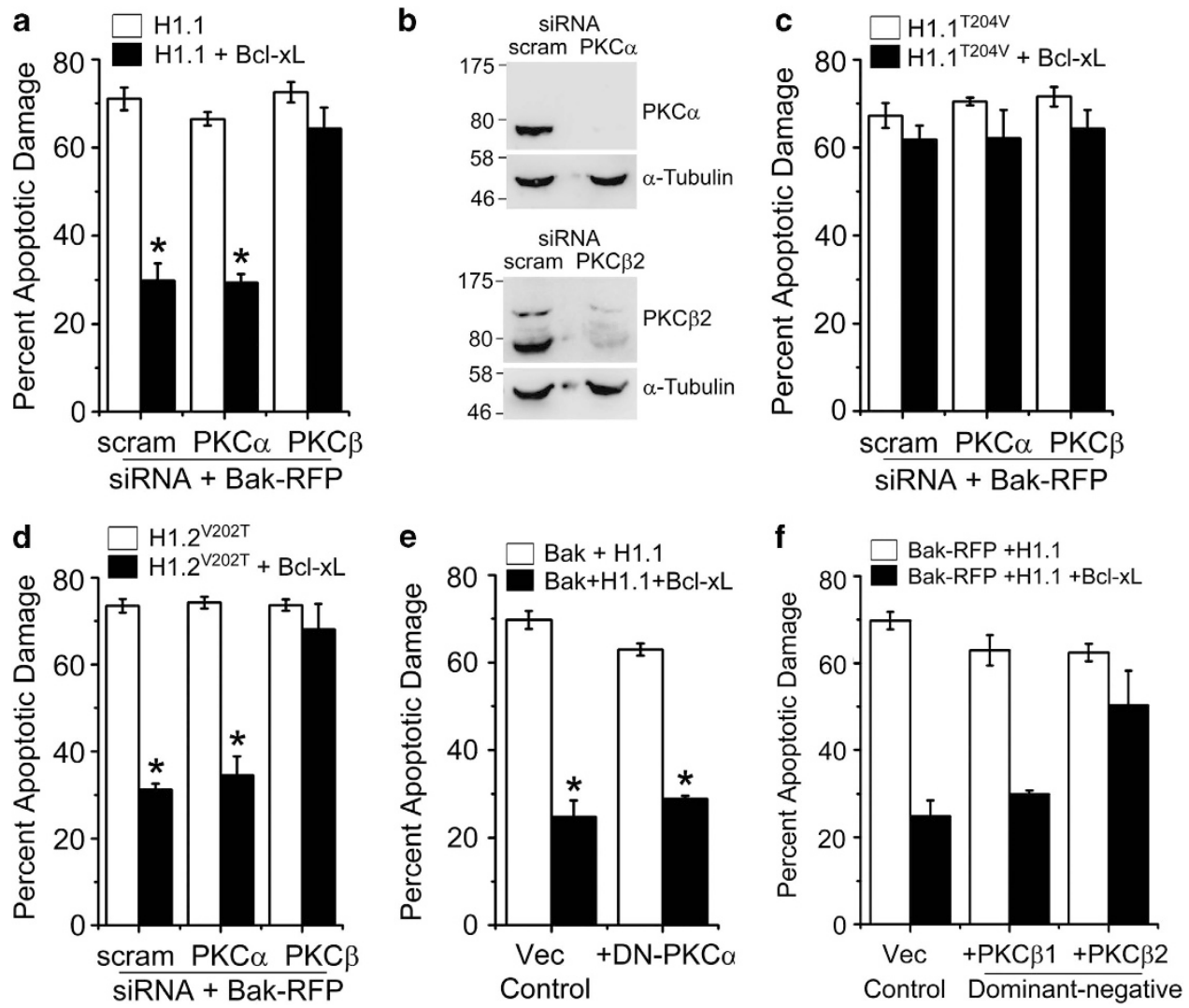

Figure 5 Apoptogenic activity in $\mathrm{LH} \mathrm{H} 1.1$ is regulated by PKC $\beta 2$ (a-c) Apoptotic damage in cells pretreated with siRNA to PKC $\alpha$ or PKC $\beta$ or a scrambled control for $48 \mathrm{~h}$ were transfected with (a) Bak-RFP $+\mathrm{H} 1.1$-EGFP $\pm \mathrm{Bcl}-\mathrm{xL}$ or (c) Bak-RFP $+\mathrm{H} 1.1^{\mathrm{T} 204 \mathrm{~V}}-\mathrm{EGFP} \pm \mathrm{Bcl}-\mathrm{xL}$. (b) Immunoblots for PKC $\alpha$ and PKC $\beta 2$ in cells treated with respective siRNA. $\alpha$-tubulin was used as the loading control. (d-f) Apoptotic damage in cells (d) pretreated with siRNA to PKC $\alpha$ or PKC $\beta$ or the scrambled control for $48 \mathrm{~h}$ were transfected with Bak-RFP $+\mathrm{H} 1.2^{\mathrm{V} 202 \mathrm{~T}}-\mathrm{EGFP} \pm \mathrm{Bcl}-\mathrm{xL}$; (e) transfected with Bak-RFP $+\mathrm{H} 1.1-\mathrm{EGFP} \pm \mathrm{Bcl}-\mathrm{xL}$ with or without DN-PKC $\alpha$; (f) transfected with Bak-RFP $+\mathrm{H} 1.1$ EGFP $\pm \mathrm{BCl}-\mathrm{xL}$ with or without DN-PKC $\beta 1$ or DN-PKC $\beta 2 .{ }^{\star} P<0.001 \mathrm{In} \mathbf{a}, \mathbf{c}$ and $\mathbf{d}-\mathbf{f}$, apoptotic damage was assessed $18 \mathrm{~h}$ post-transfection. Data are plotted as mean \pm S.D. from three independent experiments

co-transfected with $\mathrm{H} 1.2^{\mathrm{CTD}}$ (Figures $6 \mathrm{e}$ and f). Taken together, the data suggest that by preventing the degradation of the H1.2 ${ }^{\mathrm{CTD}}$, MG132 revealed the former's apoptogenic function and the consequent propagation of Bak-induced apoptosis in cells coexpressing Bcl-xL. Thus, the effect of the CTD commensurates with the apoptogenic activity observed with LH1.2.

\section{Discussion}

The LH H1.2 is a relatively recent addition to the group of nuclear resident proteins implicated in apoptotic cascades coordinated by the mitochondrion. ${ }^{8,9}$ Earlier work has demonstrated roles for $\mathrm{H} 1.2$ in triggering apoptosis in different cell types and in response to diverse stimuli. However, intrinsic molecular features underlying this function or mechanisms regulating the specific involvement of the $\mathrm{H} 1.2$ isoform are not known and are primarily investigated in this study.

The CTD of individual LH isoforms is the primary determinant of their chromatin-binding affinity, which regulates chromatin condensation, gene expression and other functions. ${ }^{15,16,28,29}$ The CTD is an intrinsically disordered domain, that is, unstructured in solution, but acquires secondary structure upon interaction with DNA,${ }^{11}$ indicating that the composition and distribution of positively charged amino acids determines its structure and hence the differential affinity or chromatin condensing property of various isoforms. It has been proposed that regions of intrinsic disorder in tail domains drive the wide-ranging molecular interactions mediated by LHs, several of which, may be determined by the CTD. ${ }^{11,15}$ These are posited to result in well-defined conformations as a consequence of interactions with a target molecule. ${ }^{16,17}$ Collectively, the dynamics of LHs are implicated in a number of functional contexts such as differentiation, genome regulation and integrity and cellular homeostasis. ${ }^{30-32}$ In this regard, analysis of histone subtypes isolated from rat brain tissue identified high-affinity isoforms $(\mathrm{H} 1.3, \mathrm{H} 1.4)$, intermediate-affinity isoforms $(\mathrm{H} 1.2, \mathrm{H} 1.5)$ and low-affinity isoform (H1.1). ${ }^{33}$ FRAP analysis of GFP-tagged subtypes in cell-based assays showed that $\mathrm{H} 1.4$ and $\mathrm{H} 1.5$ are most tightly bound to chromatin, whereas $\mathrm{H} 1.0$ and $\mathrm{H} 1.3$ have intermediate binding and $\mathrm{H} 1.1$ and $\mathrm{H} 1.2$ are weakly bound. ${ }^{12,34}$ Further, H1.3-1.5 have higher DNA condensing properties than $\mathrm{H} 1.1$ and/or $\mathrm{H} 1.2{ }^{35,36}$ suggesting the possibility that low-affinity $\mathrm{H} 1$ isoforms $(\mathrm{H} 1.1$ and $\mathrm{H} 1.2)$ may be likely early nuclear intermediates that leak into the cytoplasm to initiate apoptotic signaling. However, more 

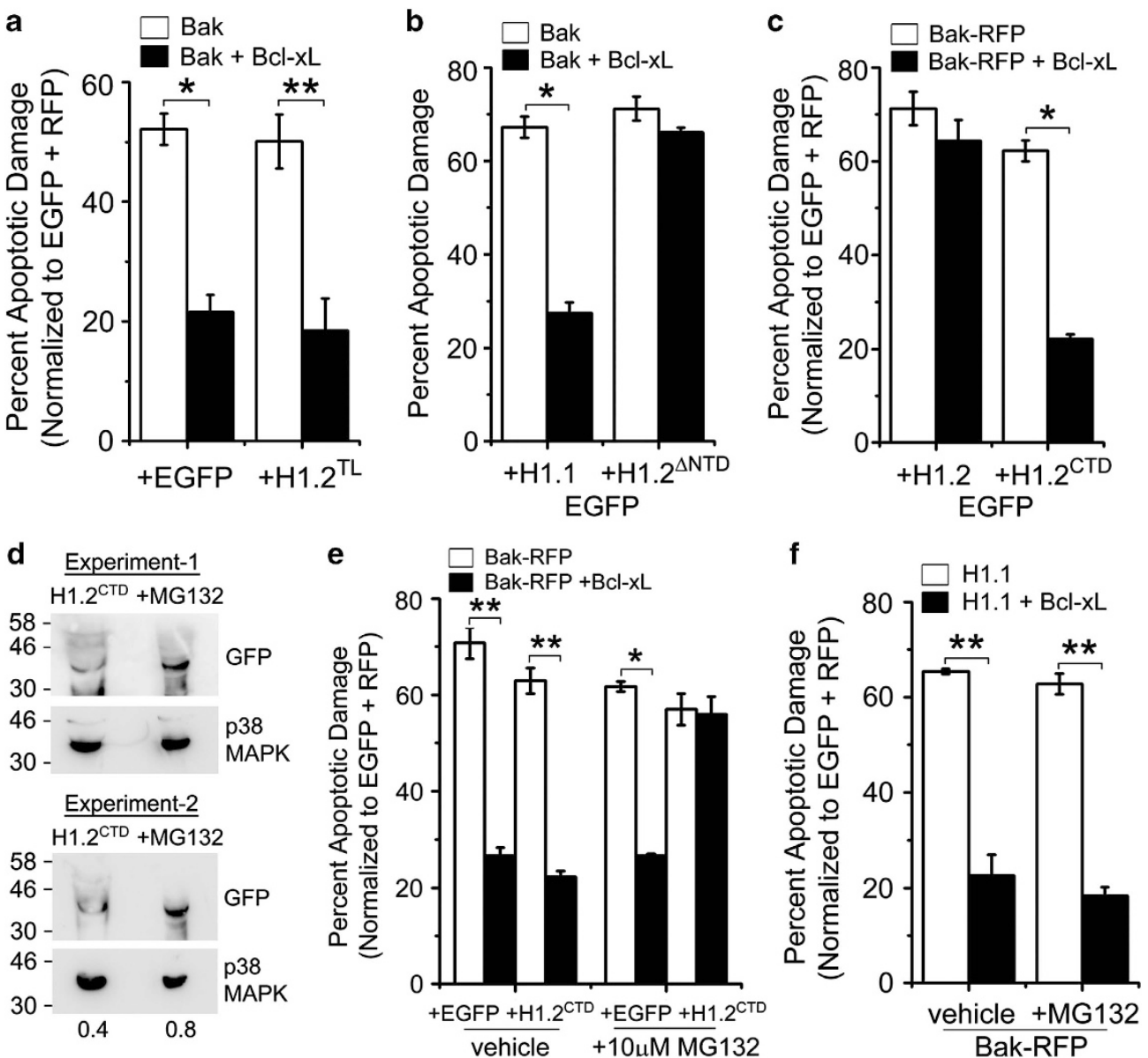

Figure 6 The H1.2 CTD is required for apoptogenic activity (a-c) Apoptotic nuclear damage in cells transfected with Bak $\pm \mathrm{H} 1.2^{\mathrm{TL}}$ (a) or Bak $\pm \mathrm{H} 1.2^{\Delta \mathrm{NTD}}$ (b) or $\mathrm{Bak}-\mathrm{RFP}+\mathrm{H} 1.2^{\mathrm{CTD}}$-EGFP (c) with or without Bcl-xL. (d) Western blot analysis of lysates generated from cells transfected with $\mathrm{H} 1.2^{\mathrm{CTD}}$-EGFP were cultured with and without MG132 $(10 \mu \mathrm{M})$ or the vehicle control for $10 \mathrm{~h}$. Immunoblots were probed with antibodies to GFP or p38MAPK (loading control). (e and f) Apoptotic nuclear damage in cells expressing the indicated recombinants and MG132 $(10 \mu \mathrm{M})$ or vehicle control added $6 \mathrm{~h}$ post-transfection. In $\mathbf{a}-\mathbf{c}$, e and $\mathbf{f}$, apoptotic nuclear damage was assessed $18 \mathrm{~h}$ post-transfection. Data plotted are mean \pm S.D. ${ }^{*} P<0.001 ;{ }^{* \star} P<0.01$

sensitive measures using biophysical and imaging approaches need to be undertaken to compare the dynamics and distributions of the different recombinants in conditions that result in distinct functional outcomes.

The data do support a necessary role for the LH CTD for apoptogenic functions and present evidence that capabilities commensurate to those presented by $\mathrm{H} 1.2$ are demonstrable in the LH isoforms H1.1 and H1.3. As H1.1 and H1.2 isoforms are detected in the cytoplasm in response to apoptotic stimuli, but only $\mathrm{H} 1.2$ is active in our experiments, it suggested that these isoforms are susceptible to differential regulation in the cytoplasm. Deletion-mutant and site-directed mutagenesis analysis implicated specific residues in the CTD, with apoptogenic function recapitulated by a recombinant CTD $\left(\mathrm{H} 1.2^{\mathrm{CTD}}\right)$. Although the intracellular interactions of the recombinant remain to be characterized more completely, it is tempting to speculate that the CTD is not only necessary but also sufficient for apoptogenic activity mediated by LH1.2. In the experimental framework employed, LHs did not antagonize the closely related anti-apoptotic protein $\mathrm{Bcl}-2$ although the generality of these two observations remain to be established. Thus, we primarily investigated interactions that impinge on interactions of $\mathrm{Bcl}-\mathrm{xL}$ and the proapoptotic protein Bak.

In contrast to the $\mathrm{H} 1.2$ isoform, apoptogenic capabilities in the isoforms $\mathrm{H} 1.1$ and $\mathrm{H} 1.3$ are repressed by the kinase PKC with gene ablation and dominant-negative approaches identifying a role for the PKC- $\beta 1$ isoform in this function. Although the site(s) where these interactions occur remain to be ascertained, the data provide a molecular explanation for the (exclusive) role of the $\mathrm{H} 1.2$ isoform in the apoptotic cascades observed in earlier reports. Although the consequences of PKC phosphorylation on functions in the mitochondrion remain to be addressed, the analysis of $\mathrm{LH}$ dynamics argues against the possibility that phosphorylation by PKC influences the spatial distribution of LHs. However, phosphorylation may promote interactions or target LHs to specific compartments or organelles facilitating apoptotic function, which remains to be investigated further. LHs modulate outcomes based on binding to chromatin, regulated in turn, by modifications of chromatin or LHs themselves. ${ }^{37-39}$ In this context, phosphorylation of tail domains of $\mathrm{H} 1$ by the cdc2 kinase promotes chromatin decondensation hence increasing accessibility to chromatin modifying enzymes. ${ }^{40,41}$ 
FRAP analysis has demonstrated that global changes in acetylation induced by TSA leads to hyper-acetylation of core histone tails but not of $\mathrm{H} 1$ and by modifying the binding of $\mathrm{H} 1$ to chromatin, increases $\mathrm{H} 1$ mobility owing to acetylationinduced alterations in chromatin structure. ${ }^{13}$

Following DNA breaks, early in the apoptotic process, the CTD of histone isoforms presents with a decrease in phosphorylation, which renders linker DNA susceptible to cleavage by apoptotic nuclease CAD/DFF40. ${ }^{42}$ Truncation mutants of recombinant $\mathrm{H} 1.0$ have shown that CTD region proximal to globular domain (97-169) is responsible for stabilization of condensed chromatin, whereas, CTD sequences more distal to globular domain (142-193) are more accessible to other proteins such as DFF40. ${ }^{42-44}$ These studies support the observations that phosphorylation of H1.1T204 by PKC suppresses its proapoptotic activity. We speculate that $\mathrm{H} 1.1$ and $\mathrm{H} 1.3$ will be apoptogenic in contexts where PKC signaling is inhibited or PKC itself is (possibly) cleaved as reported in cisplatin-induced DNA damage, characterized by the proteolytic cleavage of $\operatorname{PKC} \delta .{ }^{45}$

Our experiments show that LH function in the mitochondrion depended on several proteins apart from Bak and $\mathrm{Bcl}-\mathrm{xL}$, including Mfn-1, a regulator of mitochondrial fusion; as well as the $\mathrm{BH} 3$ domain only protein PUMA, a well-characterized antagonist of the $\mathrm{Bcl}-2$ family. It is likely that these are initiated by interactions mediated by the LH-CTD at the MOM and may determine the release of intermediates from the mitochondrion. We confirm the observation made by others that $\mathrm{H} 1.2$ selectively modulates Bak and not the closely related homolog Bax. ${ }^{9}$ Despite many similarities, the two proteins differ in their subcellular localization and are activated by $\mathrm{BH} 3$ ligands that bind distinct sites on these two proteins. ${ }^{46}$ Although the mechanism of $\mathrm{LH}$ regulation of Bak activity remains to be ascertained, LHs may bind Bak directly, thereby liberating it from a repressor complex or neutralize $\mathrm{Bcl}-\mathrm{xL}$ function by promoting the association with PUMA. Core histones and LHs are reported to destabilize mitochondria in reconstituted systems. ${ }^{47}$ We find that apoptotic cascade triggered by $\mathrm{H} 1.2$ is independent of cytochrome $c$, which differs from the observations made by Konishi et al. ${ }^{9}$ This difference may arise from the nature of the apoptotic stimuli (genotoxic drugs in the published report) or the cellular contexts, despite the core dependence on Bak in both systems. Further, as reported for metabolic stress-induced apoptosis, cell death is not necessarily always regulated by caspase activation. ${ }^{48,49}$ Although we do not know the mechanism underlying these differences, we speculate that as reported in other paradigms, restricted damage to the $\mathrm{MOM}$ alone may cause the release of AIF before cytochrome $c^{50,51}$ as the latter, if sequestered in the mitochondrial inter-membrane space by electrostatic interactions, would require additional signals for its release. ${ }^{52}$ Importantly, the experiments do not rule out the exit of cytochrome $c$, but suggest instead that AIF is a ratedetermining step in the apoptotic cascade. Given that molecular intermediates in the Bak-H1.2 apoptotic cascade are distinct, the possibility that LHs acquire apoptotic activity or recruit or relocate with additional proteins to the MOM remains to be investigated.

Collectively, the data indicate that the modulation of apoptotic outcomes may be a more prevalent feature of the
LH family indicative of a generalized function for LHs in apoptotic transduction cascades. These possibilities warrant more detailed examination of $\mathrm{LH}$ interactions with Bak in diverse physiological contexts and across evolutionary scales. ${ }^{53,54}$

\section{Materials and Methods}

Chemicals and reagents. Antibodies were procured from the following sources: AIF from Chemicon (Billerica, MA, USA); H1.2, PUMA from Abcam (Cambridge, MA, USA); HP1 $\alpha$ from Upstate Biotechnology (Lake Placid, NY, USA); $\alpha$-tubulin from Neomarker (Fremont, CA, USA); Bax, Bid (Hu-specific), $\gamma$ H2A.X, H2A.X, phospho-(Ser) PKC substrate and PKC $\alpha$ from Cell Signaling Technology (Beverely, MA, USA); GFP from BD Living Colors (BD, Franklin Lakes, NJ, USA); Bim from BD Pharmingen (BD); Drp1, Mfn1, Mfn2, p38MAPK and PKC $\beta 12$ (C-18) from Santa Cruz (Santa Cruz, CA, USA). The siRNA to BIM was from Cell Signaling Technology and all other siRNA were from Dharmacon Inc (Chicago, IL, USA). Lipofectamine was from Invitrogen (Carlsbad, CA, USA); Bisindoylmaleimide I (BIM1), Gö6976, LMB and MG-132 from Calbiochem (San Diego, CA, USA).

Cells, plasmids and transfections. HeLa and HEK 293T cell lines were maintained in DMEM supplemented with antibiotics and $10 \%$ fetal calf serum (Hyclone, Logan, UT, USA). The EGFP-tagged site-directed mutants (H1.1T204V-EGFP, H1.2-V202T-EGFP, H1.2-V202D-EGFP, H1.2 ${ }^{\mathrm{TL}}$-EGFP, H1.2 ${ }^{\triangle N T D}$ EGFP and $\mathrm{H} 1.2^{\mathrm{CTD}}$-EGFP), were made by PCR amplification following the Stratagene QuikChange Multi Site-Directed Mutagenesis manual using following primers: H1.1T204V-EGFP forward, 5'-GACGAAGCCAAAGGTTGCCAAACCCAAG-3'; H1.2V202T-EGFP forward, 5'-CGCTAAGCCCAAGACTGTCAAGCCTAAG-3'; H1. 2V202D-EGFP forward, 5'-CGCTAAGCCCAAGGATGTCAAGCCTAAG-3'; H1.2 ${ }^{\text {TL }}$ EGFP forward, 5'-GAAGATCTATGCCGGTGTCAGAGCTC-3'; H1.2 ${ }^{\text {NTTD }}$-EGFP forward, 5'-GAAGATCTATGCCGGTGTCAGAGCTC-3'; H1.2 ${ }^{\text {CTD }}$-EGFP forward, 5'-GAAGATCTATGAAAAAGGCGGGCGGAAC-3'; H1.1T204V-EGFP reverse, $5^{\prime}$-CTT GGGTTTGGCAACCTTTGGCTTCGTC-3'; H1.2V202T-EGFP reverse, 5'-CTTAG GCTTGACAGTCTTGGGCTTAGCG-3'; H1.2V202D-EGFP reverse, 5'-CTTAGGC TTGACATCCTTGGGCTTAGCG-3'; H1.2 ${ }^{\text {TL }}$-EGFP reverse, 5'"-CTCAAGCTTAAC CTTGGGCTTGGCTTC-3'; H1.2 ${ }^{\Delta \text { NTD }} /$ H1.2 $2^{\text {CTD }}$-EGFP reverse, $5^{\prime}$-CGGGATCCTT TCTTCTTGGGCG- $3^{\prime}$. Recombinant Bak constructs were made by PCR amplifying Bak ORF (Origene) and ligating into fluorophore-tagged vectors. All constructs were in the pEGFP-N1 or pEGFP-N3 backbone and the sequences were verified by automated sequencing (NCBS, Bangalore, India). Dominant-negative PKC constructs were from Addgene (Cambridge, MA, USA). Dominant-negative caspase 9 (DNC9) construct was a kind gift from C. Vincenz (University of Michigan Medical School, Ann Arbor, MI, USA) and the Bcl-xL plasmid from Richard J. Youle (NIH, Bethesda, MD, USA).

Cells $\left(0.05 \times 10^{6} / \mathrm{ml}\right)$ were plated in 24-well plate $15-18 \mathrm{~h}$ before transfection with recombinants: EGFP, RFP, Bak-EGFP, Bak-RFP $(0.8 \mu \mathrm{g})$; Bcl-xL, DNC9, H1.2-EGFP or H1.1-EGFP and related recombinants (1.5-2.5 $\mu \mathrm{g}$ ) and pcDNA3.0 (empty vector control) to equalize the concentration of DNA across transfection groups. For transfections with siRNA, cells plated as above, were transfected with $100 \mathrm{nM}$ siRNA and used in functional or biochemical assays $48 \mathrm{~h}$ later.

Cells were stained for $3 \mathrm{~min}$ with the Hoechst $33342(1 \mu \mathrm{g} / \mathrm{ml})$ at ambient temperature and nuclear morphology scored in EGFP or RFP positive cells by fluorescence microscopy.

Immunostaining. Cells fixed with $1-4 \%$ paraformaldehyde $(15-20 \mathrm{~min})$ at ambient temperature were permeabilized using ice-cold $100 \%$ methanol for $10 \mathrm{~min}$. Samples were blocked with $5 \%$ BSA in $0.3 \%$ Triton-X100-PBS and incubated with $1: 200$ anti-H2A.X or anti- $\gamma$ H2A.X overnight at $4{ }^{\circ} \mathrm{C}$ diluted in blocking buffer. Secondary antibodies (Alexa Fluor-647) were diluted $(1: 500)$ in blocking buffer and samples incubated for $1 \mathrm{~h}$ at room temperature. Images were acquired using Zeiss LSM 510 Meta (63X NA 1.4 objective lens; Carl Zeiss, Oberkochen, Germany). Fluorescence images of cells were recorded with sequential excitation and emission conditions for EGFP, RFP or Alexa Fluor-647.

Western blot analysis. Cells $\left(0.3-0.5 \times 10^{6}\right)$ were lysed in a SDS lysis buffer. Whole-cell lysates were resolved by SDS-PAGE and transferred to nitrocellulose membrane (GE Healthcare, Bangalore, India) and incubated overnight at $4{ }^{\circ} \mathrm{C}$ with primary antibodies at concentrations recommended by 
the manufacturers. Membrane was washed three times with TBS-Tween20 followed by HRP-conjugated secondary antibody (CST, $1: 1000$ dilution) for $1 \mathrm{~h}$ at room temperature. Membranes were developed by exposure to X-ray film using either an Amersham Hyperprocessor (Princeton, NJ, USA) or an ImageQuant LAS 4000 Biomolecular Imager (GE Healthcare). Films were scanned and intensity of bands were quantified with ImageJ software (NIH, Bethesda, MD, USA).

Subcellular fractionation. Cells $\left(2.5 \times 10^{6}\right)$ were used as input for subcellular fractionation. Cytoplasmic and nuclear fractions were obtained following instructions provided with the NE-PER Nuclear and Cytoplasmic extraction kit (Thermo Scientific, Waltham, MA, USA). Equivalent volumes of nuclear and cytoplasmic fractions were boiled in SDS lysis buffer for western blot analysis.

FRAP analysis. Cells $\left(0.3 \times 10^{6}\right)$ were plated $15-18 \mathrm{~h}$ before transfection with recombinants: H1.2-EGFP or H1.1-EGFP or related recombinants $(0.1 \mu \mathrm{g})$ and Bak-RFP $(0.7 \mu \mathrm{g})$. Fluorescence recovery after photo-bleaching (FRAP) analysis was performed $14-16 \mathrm{~h}$ post transfection according to a previously published protocol ${ }^{34}$ using a Zeiss LSM 510 Meta NLO, Plan-Apochromat 63X NA 1.4 oil objective. The dynamics of fluorescence recovery of $\sim 1.5 \mu \mathrm{m}$ photobleached region was calculated using custom-written MATLAB routines. All FRAP curves were normalized to prebleach values after background subtraction and photo-bleaching correction.

Statistical methods. All graphs show data presented as mean \pm S.D. derived minimally from three-four independent experiments unless stated otherwise. FRAP analysis is presented as mean \pm S.E.M. Statistical significance was calculated using the two-population Student's t-test, with the following confidence intervals: ${ }^{*} 99.9 \%$ and ${ }^{*} 99 \%$.

\section{Conflict of Interest}

The authors declare no conflict of interest.

Acknowledgements. We acknowledge the NCBS Central Imaging and FlowCytometry Facility, and Soumya Gupta, MBI, Singapore for assistance with the manuscript. The study was funded by core funds from NCBS, TIFR. MG is supported by a fellowship from the Department of Biotechnology, Mysore University, Mysore, India.

1. Cory S, Huang DC, Adams JM. The Bcl-2 family: roles in cell survival and oncogenesis. Oncogene 2003; 22: 8590-8607.

2. Youle RJ, Strasser A. The BCL-2 protein family: opposing activities that mediate cell death. Nat Rev Mol Cell Biol 2008; 9: 47-59.

3. Ashkenazi A, Dixit VM. Death receptors: signaling and modulation. Science 1998; 281: $1305-1308$

4. Roos WP, Kaina B. DNA damage-induced cell death by apoptosis. Trends Mol Med 2006; 12: $440-450$

5. Nowsheen S, Yang ES. The intersection between DNA damage response and cell death pathways. Exp Oncol 2012; 34: 243-254.

6. Leu JI, Dumont P, Hafey M, Murphy ME, George DL. Mitochondrial p53 activates Bak and causes disruption of a Bak-Mcl1 complex. Nat Cell Biol 2004; 6: 443-450.

7. Chipuk JE, Kuwana T, Bouchier-Hayes L, Droin NM, Newmeyer DD, Schuler M et al. Direct activation of Bax by p53 mediates mitochondrial membrane permeabilization and apoptosis. Science 2004; 303: 1010-1014.

8. Lindenboim L, Borner C, Stein R. Nuclear proteins acting on mitochondria. Biochim Biophys Acta 2011; 1813: 584-596.

9. Konishi A, Shimizu S, Hirota J, Takao T, Fan Y, Matsuoka Y et al. Involvement of histone H1.2 in apoptosis induced by DNA double-strand breaks. Cell 2003; 114: 673-688.

10. Hansen JC, Lu X, Ross ED, Woody RW. Intrinsic protein disorder, amino acid composition, and histone terminal domains. J Biol Chem 2006; 281: 1853-1856.

11. Lu X, Hamkalo B, Parseghian MH, Hansen JC. Chromatin condensing functions of the linker histone $\mathrm{C}$-terminal domain are mediated by specific amino acid composition and intrinsic protein disorder. Biochemistry 2009; 48: 164-172.

12. Th'ng JP, Sung R, Ye M, Hendzel MJ. H1 family histones in the nucleus. Control of binding and localization by the C-terminal domain. J Biol Chem 2005; 280: 27809-27814.

13. Raghuram N, Carrero G, Stasevich TJ, McNally JG, Th'ng J, Hendzel MJ. Core histone hyperacetylation impacts cooperative behavior and high-affinity binding of histone $\mathrm{H} 1$ to chromatin. Biochemistry 2010; 49: 4420-4431.
14. Happel N, Doenecke D. Histone $\mathrm{H} 1$ and its isoforms: contribution to chromatin structure and function. Gene 2009; 431: 1-12.

15. Caterino TL, Fang H, Hayes JJ. Nucleosome linker DNA contacts and induces specific folding of the intrinsically disordered $\mathrm{H} 1$ carboxyl-terminal domain. Mol Cell Biol 2011; 31: 2341-2348.

16. McBryant SJ, Lu X, Hansen JC. Multifunctionality of the linker histones: an emerging role for protein-protein interactions. Cell Res 2010; 20: 519-528.

17. Kalashnikova AA, Winkler DD, McBryant SJ, Henderson RK, Herman JA, DeLuca JG et al. Linker histone $\mathrm{H} 1.0$ interacts with an extensive network of proteins found in the nucleolus. Nucleic Acids Res 2013; 41: 4026-4035

18. Green DR, Kroemer G. The pathophysiology of mitochondrial cell death. Science 2004; 305: 626-629.

19. Lorenzo HK, Susin SA, Penninger J, Kroemer G. Apoptosis inducing factor (AIF): a phylogenetically old, caspase-independent effector of cell death. Cell Death Differ 1999; 6: $516-524$

20. Rogakou EP, Pilch DR, Orr AH, Ivanova VS, Bonner WM. DNA double-stranded breaks induce histone H2AX phosphorylation on serine 139. J Biol Chem 1998; 273: 5858-5868.

21. Artus C, Boujrad H, Bouharrour A, Brunelle MN, Hoos S, Yuste VJ et al. AlF promotes chromatinolysis and caspase-independent programmed necrosis by interacting with histone H2AX. Embo J 2010; 29: 1585-1599.

22. Vela L, Gonzalo O, Naval J, Marzo I. Direct interaction of Bax and Bak proteins with Bcl-2 homology domain $3(\mathrm{BH} 3)$-only proteins in living cells revealed by fluorescence complementation. J Biol Chem 2013; 288: 4935-4946.

23. Bouillet $\mathrm{P}$, Strasser A. BH3-only proteins-evolutionarily conserved proapoptotic Bcl-2 family members essential for initiating programmed cell death. J Cell Sci 2002; 115: 1567-1574.

24. Cassidy-Stone A, Chipuk JE, Ingerman E, Song C, Yoo C, Kuwana T et al. Chemical inhibition of the mitochondrial division dynamin reveals its role in Bax/Bak-dependent mitochondrial outer membrane permeabilization. Dev Cell 2008; 14: 193-204.

25. Brooks $C$, Wei $Q$, Feng L, Dong G, Tao $Y$, Mei L et al. Bak regulates mitochondrial morphology and pathology during apoptosis by interacting with mitofusins. Proc Natl Acad Sci USA 2007; 104: 11649-11654.

26. Park $\mathrm{CH}$, Kim KT. Apoptotic phosphorylation of histone $\mathrm{H} 3$ on Ser-10 by protein kinase $\mathrm{C}$ delta. PLoS One 2012; 7: e44307.

27. Metzger E, Imhof A, Patel D, Kahl P, Hoffmeyer K, Friedrichs N et al. Phosphorylation of histone H3T6 by PKC beta(I) controls demethylation at histone H3K4. Nature 2010; 464: 792-796.

28. Hendzel MJ, Lever MA, Crawford E, Th'ng JP. The C-terminal domain is the primary determinant of histone $\mathrm{H} 1$ binding to chromatin in vivo. J Biol Chem 2004; 279: 20028-20034.

29. Allan J, Mitchell T, Harborne N, Bohm L, Crane-Robinson C. Roles of H1 domains in determining higher order chromatin structure and H1 location. J Mol Biol 1986; 187: 591-601.

30. Popova EY, Grigoryev SA, Fan Y, Skoultchi Al, Zhang SS, Barnstable CJ. Developmentally regulated linker histone $\mathrm{H} 1 \mathrm{c}$ promotes heterochromatin condensation and mediates structural integrity of rod photoreceptors in mouse retina. J Biol Chem 2013; 288: 17895-17907.

31. Li JY, Patterson M, Mikkola HK, Lowry WE, Kurdistani SK. Dynamic distribution of linker histone H1.5 in cellular differentiation. PLoS Genet 2012; 8: e1002879.

32. Pérez-Montero $S$, Carbonell $A$, Morán $T$, Vaquero $A$, Azorín $F$. The embryonic linker histone $\mathrm{H} 1$ variant of Drosophila, $\mathrm{dBigH} 1$, regulates zygotic genome activation. Dev Cell 2013; 26: 578-590.

33. Orrego M, Ponte I, Roque A, Buschati N, Mora X, Suau P. Differential affinity of mammalian histone H1 somatic subtypes for DNA and chromatin. BMC Biol 2007; 5: 22.

34. Bhattacharya D, Mazumder A, Miriam SA, Shivashankar GV. EGFP-tagged core and linker histones diffuse via distinct mechanisms within living cells. Biophys J 2006; 91: 2326-2336.

35. Khadake JR, Rao MR. DNA- and chromatin-condensing properties of rat testes H1a and $\mathrm{H} 1 \mathrm{t}$ compared to those of rat liver $\mathrm{H} 1 \mathrm{bdec} ; \mathrm{H} 1 \mathrm{t}$ is a poor condenser of chromatin. Biochemistry 1995; 34: 15792-15801.

36. Liao LW, Cole RD. Differences among subfractions of $\mathrm{H} 1$ histone in their interactions with linear and superhelical DNA. Circular dichroism. J Biol Chem 1981; 256: 6751-6755.

37. Misteli T, Gunjan A, Hock R, Bustin M, Brown DT. Dynamic binding of histone $\mathrm{H} 1$ to chromatin in living cells. Nature 2000; 408: 877-881.

38. Kamieniarz K, Izzo A, Dundr M, Tropberger P, Ozretić L, Kirfel J et al. A dual role of linker histone H1.4 Lys 34 acetylation in transcriptional activation. Genes Dev 2012; 26: 797-802.

39. Yang SM, Kim BJ, Toro LN, Skoultchi Al. H1 linker histone promotes epigenetic silencing by regulating both DNA methylation and histone $\mathrm{H} 3$ methylation. Proc Natl Acad Sci USA 2013; 110: 1708-1713.

40. Horn PJ, Carruthers LM, Logie C, Hill DA, Solomon MJ, Wade PA et al. Phosphorylation of linker histones regulates ATP-dependent chromatin remodeling enzymes. Nat Struct Bio 2002; 9: 263-267.

41. Contreras A, Hale TK, Stenoien DL, Rosen JM, Mancini MA, Herrera RE. The dynamic mobility of histone $\mathrm{H} 1$ is regulated by cyclin/CDK phosphorylation. Mol Cell Biol 2003; 23: 8626-8636.

42. Widlak P, Kalinowska M, Parseghian MH, Lu X, Hansen JC, Garrard WT. The histone H1 C-terminal domain binds to the apoptotic nuclease, DNA fragmentation factor (DFF40/ CAD) and stimulates DNA cleavage. Biochemistry 2005; 44: 7871-7878.

43. Guo CY, Brautigan DL, Larner JM. Ionizing radiation activates nuclear protein phosphatase-1 by ATM-dependent dephosphorylation. J Biol Chem 2002; 277 41756-41761. 
44. Kratzmeier M, Albig W, Hanecke K, Doenecke D. Rapid dephosphorylation of $\mathrm{H} 1$ histones after apoptosis induction. J Biol Chem 2000; 275: 30478-30486.

45. Basu A, Woolard MD, Johnson CL. Involvement of protein kinase C-delta in DNA damageinduced apoptosis. Cell Death Differ 2001; 8: 899-908.

46. Leshchiner ES, Braun CR, Bird GH, Walensky LD. Direct activation of full-length proapoptotic BAK. Proc Natl Acad Sci USA 2013; 110: E986-E995.

47. Cascone A, Bruelle C, Lindholm D, Bernardi P, Eriksson O. Destabilization of the outer and inner mitochondrial membranes by core and linker histones. PLOS One 2012; 7: e35357.

48. Deas O, Dumont C, MacFarlane M, Rouleau M, Hebib C, Harper F et al. Caspaseindependent cell death induced by anti-CD2 or staurosporine in activated human peripheral T lymphocytes. J Immunol 1998; 161: 3375-3383.

49. Xiang J, Chao DT, Korsmeyer SJ. BAX-induced cell death may not require interleukin 1 beta-converting enzyme-like proteases. Proc Natl Acad Sci USA 1996; 93: 14559-14563.

50. Daugas E, Susin SA, Zamzami N, Ferri KF, Irinopoulou T, Larochette N et al. Mitochondrio-nuclear translocation of AIF in apoptosis and necrosis. Faseb J 2000; 14 : 729-739.
51. Yu SW, Wang H, Poitras MF, Coombs C, Bowers WJ, Federoff HJ et al. Mediation of poly(ADP-ribose) polymerase-1-dependent cell death by apoptosis-inducing factor. Science 2002; 297: 259-263.

52. Uren RT, Dewson G, Bonzon C, Lithgow T, Newmeyer DD, Kluck RM. Mitochondrial release of pro-apoptotic proteins: electrostatic interactions can hold cytochrome $\mathrm{c}$ but not Smac/DIABLO to mitochondrial membranes. J Biol Chem 2005; 280: 2266-2274.

53. Bender CE, Fitzgerald P, Tait SW, Llambi F, McStay GP, Tupper DO et al. Mitochondrial pathway of apoptosis is ancestral in metazoans. Proc Natl Acad Sci USA 2012; 109: 4904-4909.

54. Oberst A, Bender C, Green DR. Living with death: the evolution of the mitochondrial pathway of apoptosis in animals. Cell Death Differ 2008; 15: 1139-1146.

(c) (1) (2)(2) Cell Death and Disease is an open-access journal published by Nature Publishing Group. This work is licensed under a Creative Commons Attribution-NonCommercialShareAlike 3.0 Unported License. To view a copy of this license, visit http://creativecommons.org/licenses/by-nc-sa/3.0/

Supplementary Information accompanies this paper on Cell Death and Disease website (http://www.nature.com/cddis) 